\title{
EPIPHYTIC MICROALGAE AND WATER QUALITY INTERACTION AT NORTH DELTA- EGYPT
}

\author{
Deyab M. A. ${ }^{*}$, Nemat Alla M. M. and El- Naggar M. A. \\ Botany Department, Faculty of Science at Damietta, Egypt
}

\begin{abstract}
The present work was aimed to study local variations of epiphytic microalgal distribution, biomass, and abundance at the northern part of Delta Egypt (Damietta, ElDeepa, Qualabshu, Kafr- Elshiekh and Rosetta) on the surface of a wide spread hydrophyte (Phragmites australis) during the year 2005. One hundred and forty one epiphytic algal species were recorded at the stations. The most dominant class of these species was Bacillariophyta; it represented $95.7 \%$ of the total epiphytic species. Dinoflagellate was represented by 5 species, while each of Cyanophyta and Chlorophyta was represented by only one species. The distribution and abundance of these epiphytic microalgae were studied to be used as bioindicators of water quality assessment. To achieve this purpose, physicochemical analysis of water and biological analysis of epiphytic microalgae were evaluated. The results of diversity index revealed that water quality fluctuated from heavy to slight polluted water while the saprobity level point out to a univocal oligosaprobity and universal $\alpha$ - mesosaprobity.
\end{abstract}

\section{Introduction}

Epiphytic microalgae are common constituents to determine the trophic status of aquatic ecosystems (Vis et al., 2006; Cook, 2007), biomass (Zimba, 1995), and as a food source for higher trophic levels (Eli et al., 2004; Anna et al., 2006), primary productivity, water quality and food web interactions in aquatic ecosystems (Lisa and Fred, 2003). The loosely attached and tightly attached epiphytic algae exhibit different physiological activities (Burkholder et al., 1990). The presence of epiphytic microalgae is influenced by some biotic (the host plant architecture (Vis et al., 2006)) and abiotic factors, such as the amount of nutrient in the water (Frankovich et al., 2006), the light regime (Muller, 1995), water pollution (Olmsted and Gomez, 1995) and the disturbance of water by rain and wind (Paul and Hopson, 1997). The last two factors are particularly important in determining the vertical zonation along with the depth gradient grazing (Muller, 1994) and the seasonal variations (Goldsborough and Hickman, 1991).

Therefore, the present work was aimed to study local variations of epiphytic microalgal distribution, biomass, and abundance at different stations of the northern part of Delta Egypt on the surface of a wide spread hydrophyte (Phragmites australis). 


\section{Materials and Methods}

To carry out this work, five stations (Damietta, El- Deepa, Qualabshu, KafrElshiekh and Rosetta) were selected along the northern part of Nile River as a study area as shown in the map (Fig. 1).

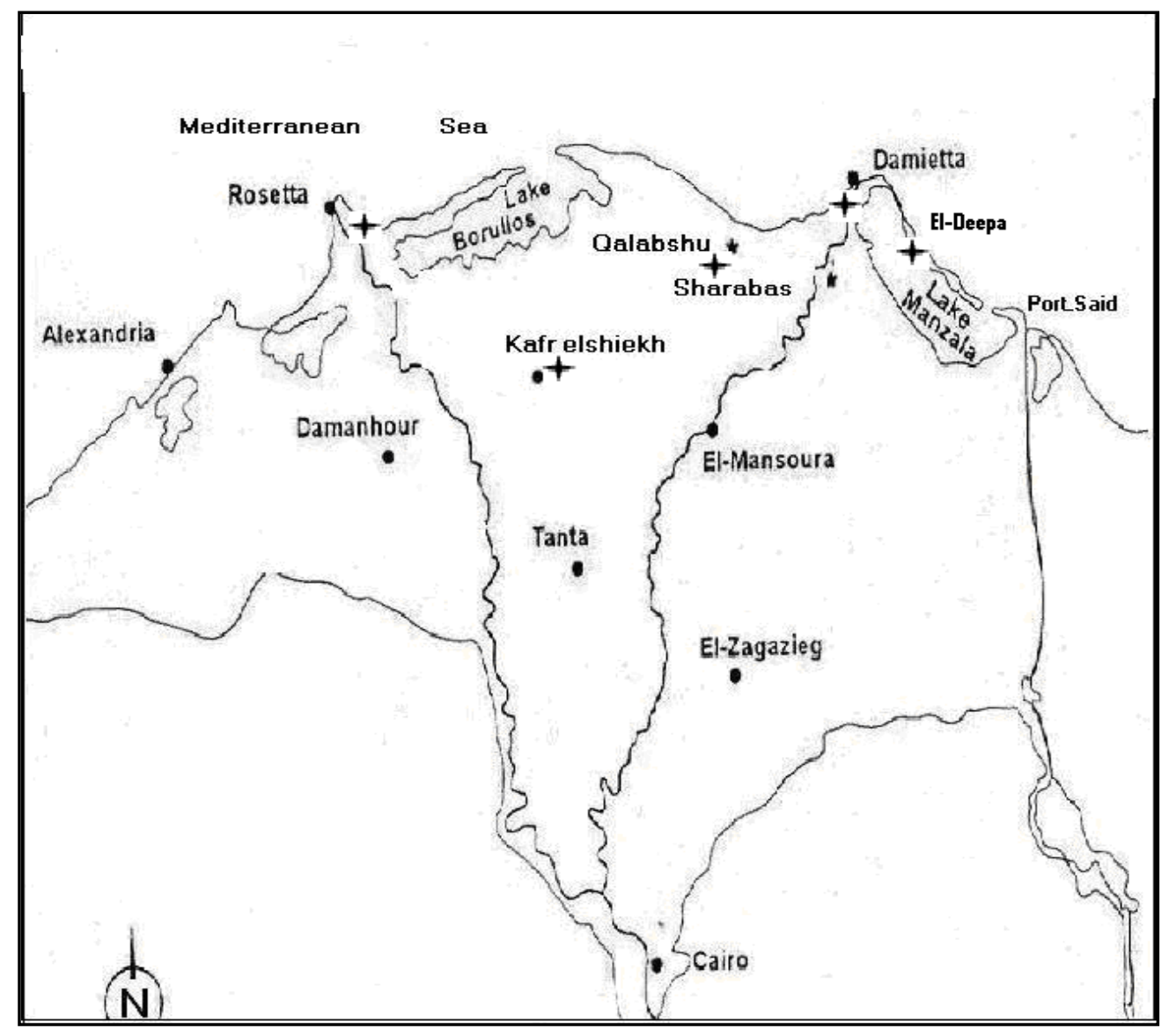

Figure 1. A map representing the different stations of the study area

\section{Physicochemical measurements}

The surface water samples were collected two times in each season all over one year (from January 2005 to January, 2006). Water temperature was measured using a Celius Thermometer, $\mathrm{pH}$ was determined using a Horizon Ecology Co $\mathrm{pH}$ meter 5995, water salinity as well as the electric conductivity were measured directly using YSI Model 33 (yellow springs) S-C-T Meter, Biochemical oxygen demands (BOD), chlorides, total hardness and total phosphorus were measured 
according to APHA (1989), dissolved oxygen was measured according to Wood (1975), ortho-phosphate and reactive silica were measured using the procedure of ROPME (1983), nitrate-N, nitrite-N and total alkalinity were measured according to Strickland and Parsons (1965), ammonia-N and dissolved organic nitrogen (DON) were determined according to Golterman et al. (1978). Sodium and Potassium were determined according to Allen et al. (1974) using a flame photometer type $\mathrm{M} 7 \mathrm{D}$. $\mathrm{Cu}, \mathrm{Fe}, \mathrm{Zn}, \mathrm{Co}$ and $\mathrm{Pb}$ were analyzed using a perkinElmer double beam 2380 atomic absorption spectrophotometer (Chapman and Pratt, 1961).

\section{Collection and identification of epiphytic algal samples}

For studying the epiphytic microalgae, a known surface area of the hydrophyte $\left(10 \mathrm{~cm}^{2}\right)$ was seasonally taken twice at three levels (surface $=\mathrm{S}$, middle $=\mathrm{M}$ and bottom = B). The preserved as well as fresh samples were examined microscopically for the qualitative analysis of epiphytic algae according to Cronberg (1982). Generally, identification of the present algal taxa (species and varieties) was made according to Zabelena et al. (1954), Hendy (1964), Philipose (1967), Cyrus and Sladecek (1973), Hindak et al. (1975) and Prescott (1978). While quantitative analysis was performed using a Sedwick-Rafter counting chamber (Ganf, 1974).

\section{Assessement of water quality}

Biological assessment of water quality was carried out by using diversity index (Shannon and Weaver, 1963) and saprobic index (Sladecek, 1973).

\section{Statistical analysis}

The cluster analysis, an explicit way of identifying similar groups in row data, was performed (Clifford and Stephenson, 1975). A2-tailed Pearson product moment correlation was performed using software program SPSS to examine the relationship between all physicochemical and biological parameters.

\section{Result and Discussion}

The obtained results showed that there was a general shift of water $\mathrm{pH}$ to the alkaline side $(8-8.4)$ and an elevation in temperature value $\left(19.5-23{ }^{\circ} \mathrm{C}\right)$ suitable for epiphytic microalgal growth (Table 1). The changes in water characteristics would subsequently lead to qualitative and quantitative changes in the epiphytic microalgal organisms (Janne and Jani, 2005). The biological activities of phytoplankton and epiphytic microalgae especially photosynthesis and respiration has been controlled by the temperature and $\mathrm{pH}$ of aquatic systems, (Reynolds, 1976; Sukran et al., 2002). The mean value of water salinity was the lowest at Damietta station $(2.3 \mathrm{~g} / \mathrm{L})$ which may be due to the discharged drainage water and highest at El- Deepa $(4.9 \mathrm{~g} / \mathrm{L})$ station probably due to the shallow water evaporation as previously indicated by El- Naggar (2002). 
Table (1): Annual mean values of water parameters of five stations at north Delta Egypt.

\begin{tabular}{|c|c|c|c|c|c|}
\hline Variables & Damietta & El- Deepa & Qualabshu & Kafr- Elshiekh & Rosetta \\
\hline Temperature ${ }^{\circ} \mathbf{C}$ & 20.3 & 19.5 & 22 & 21.3 & 23 \\
\hline pH & 8.4 & 8 & 8 & 8.1 & 8.3 \\
\hline Total alkalinity (meq/L) & 1.4 & 2.4 & 2.1 & 3.2 & 7.3 \\
\hline Total hardeness (meq/L) & 96.4 & 153.2 & 108.5 & 130.2 & 48.7 \\
\hline Dissolved oxygen (mg/L) & 14.8 & 7.6 & 5.1 & 4.1 & 8.2 \\
\hline Salinity (mg/L) & 2314 & 4941 & 3424 & 4252 & 4314 \\
\hline Chloride (mg/L) & 1542 & 2523 & 1900 & 2046 & 2023 \\
\hline Sodium $(\mathrm{mg} / \mathrm{L})$ & 458 & 834.7 & 737 & 780 & 793 \\
\hline Potassium $(\mathrm{mg} / \mathrm{L})$ & 136.5 & 288 & 233.7 & 208 & 237.2 \\
\hline Nitrate $(\mathrm{mg} / \mathrm{L})$ & 0.6 & 0.12 & 0.19 & 0.18 & 0.11 \\
\hline Nitrite $(\mathrm{mg} / \mathrm{L})$ & 0.14 & 0.04 & 0.04 & 0.04 & 0.05 \\
\hline Ammonia (mg/L) & 0.2 & $\mathbf{0 . 0 3}$ & 0.016 & 0.037 & 0.017 \\
\hline D O N (mg/L) & 1.6 & 0.82 & 1.23 & 1.4 & 2.3 \\
\hline Ortho- phosphate (mg/L) & $\mathbf{0 . 3 3}$ & 0.12 & 0.33 & 0.1 & 0.13 \\
\hline Total phosphate (mg/L) & 3.6 & 2.45 & 2.1 & 1.9 & 1.9 \\
\hline Silica $(\mathrm{mg} / \mathrm{L})$ & 1.3 & 1.6 & 2 & 1.04 & 1.75 \\
\hline T D S (mg/L) & 236 & 816 & 739 & 803 & 602.3 \\
\hline B O D (mg/L) & 3.7 & 4.3 & 3.5 & 6.5 & 3.4 \\
\hline Cupper (mg/L) & 0.3 & 0.14 & 0.09 & 0.1 & 0.18 \\
\hline Cobalt (mg/L) & 0.03 & 0.33 & 0.19 & 0.07 & 0.07 \\
\hline Zinc (mg/L) & 0 & 0.37 & 0.08 & 0.15 & 0.21 \\
\hline Lead $(\mathrm{mg} / \mathrm{L})$ & 0 & 0.15 & $\mathbf{0}$ & 0.15 & 0 \\
\hline Iron $(\mathrm{mg} / \mathrm{L})$ & 0.11 & 0.23 & 0.3 & 0.05 & 0.07 \\
\hline
\end{tabular}

The mean values of total alkalinity in the present investigation clearly indicated the presence of local variations $(1.4-7.3 \mathrm{meq} / \mathrm{L})$. Such variation may be related to the discharged water in the aquatic ecosystem (Adam et al., 1993; Abdel - Baky, 2006). On the other hand, the lowest mean value of dissolved oxygen content which was recorded at Kafr- Elshiekh may be probably due to the discharge of high quantities of domestic wastes; while the recorded highest value at Damietta may be due to increased photosynthetic activity of phytoplankton, epiphytic algal species and green hydrophytes (Cook, 2007). The rise in chlorides and sodium contents may be due to the agriculture activity (Golterman, 1999). However, sodium value was usually much more than potassium value at the studied stations and sodium chloride plays a major role in the community structure of algal flora (Lund, 1965; Zaid, 1993; El-Naggar, 2002).

The obtained results show also that nitrate concentrations were higher than nitrite. This seems to be related to the nitrogen regeneration and the chemical or biological oxidation-reduction reactions (Turkoglu and Koray, 2002). Meanwhile, total phosphorous, dissolved organic nitrogen and ammonia content was fluctuated in the stations under investigation according to the pollution state of 
water (Janne and Jani, 2005) where industrial, agricultural and urban sewage water carried high amount of phosphate and ammonia (Madkour, 2000; AbdelBaky, 2001; Caccia and Boyer, 2005) as well as to the high phosphorus consumption by high vegetation of phytoplankton (Polat and Isik, 2002; Cook, 2007). Moreover, ortho-phosphate exhibited local variations, not only due to the high growth of phytoplankton, but also to the agricultural and sewage discharges (Juttner et al., 1996).

On the other hand, the fluctuation of mean values of silica which were recorded in the stations under study may be related to the level of diatom growth and decaying processes. The decline in silica concentration was accompanied by increased diatoms growth (El- Naggar, 2002) while high silicate content may be attributed to the decay of diatoms, fishes and the decomposition of organic matter (Juttner et al., 1996; Abdel - Baky, 2006). The variation of biochemical oxygen demand (B.O.D) was related to pollution status of water. An increase of the amount of discharged wastes could increase the values of B.O.D (Abdel- Baky, 2001). Similarly, total dissolved salts and heavy metals contents showed varied fluctuations which may be related to the types and amounts of discharged water (Abdel- Baky, 2001) and salinity level (Aziz et al., 1996).

Cluster analysis of water variables reveals that Damietta and El- Deepa stations were grouped as minor subgroups (Figure 2). On the contrary, Qualabshu and Kafr-Elshiekh stations were separated into different groups while Rosetta station stands as an intermediate group between the five subgroups.



Figure 2. Similarity dendrogram between stations at different seasons according to the physico-chemical parameters using Bray-Curtis measure (cluster analysis)

This division was related to the similarities between Damietta and El- Deepa stations according to their water variables and both are different of the other three stations. Similar observations were also detected in stations relating to their variables as recorded by Abdel- Baky (2006) which were in agreement with our results. 
The results of Pearson moment correlation coefficient ( $r$ ) between water variables showed that water temperature was positively correlated with dissolved organic nitrogen and total alkalinity but negatively correlated with chloride, total hardness and lead content (Table 2). These results revealed that temperature might increase the organic nitrogen and alkalinity. This trend seemed to be in accordance with that observed by Abdel-Hamid et al. (1992) and Abdel-Baky (2001) at different sites along the Rive Nile and the Delta region. More than one parameter was correlated positively with the $\mathrm{pH}$ ( $\mathrm{Si}$, ortho-phosphates, total phosphorus, nitrite, ammonia, dissolved oxygen, biological oxygen demand and copper content) while some others were negatively correlated (total dissolved salts and electrical conductivity, salinity, nitrates, sodium, potassium, zinc and lead content). These results were in accordance with those reported by Hans, (2006) where $\mathrm{pH}$ was positively correlated with total alkalinity and dissolved oxygen.

There were positive correlations between total dissolved salts, electric conductivity salinity, sodium, potassium, zinc and lead contents confirming their relationships. These interrelations might be due to the occurrence and accumulation of sodium, potassium, zinc and lead. With these pertinent interrelations, retractions of nitrogenous compounds (organic nitrogen, ammonia, and nitrate) in addition to silicate, orthophosphate, total phosphorus and biological oxygen demand were augmented as indicated by Adel-Baky (2001, 2006). The correlations of total hardness with chlorides and salinity may indicate that hardness might be resulted from the increase in these variables. On the other hand, orthophosphate and total phosphorus were positively correlated with nitrate content, ammonia, copper. These observations are in accordance with those previously detected by Shaaban-Dessouki et al. (1993) and Adel-Baky (2001, 2006).

However, the decrease in sodium caused an elevation of ammonia content and biological oxygen demand. These results give an indication to what extent these variables could interfere with the environment of living organisms. The fluctuations of these environmental factors might provoke variations in biota of a restricted region. Therefore, growth and distribution of living organisms among which the epiphytic microalgae are predicted to be greatly influenced.

Concerning the biological analysis of epiphytic microalgae, 141 species were recorded as epiphytic microalgae on Phragmites australis, through the entire period of investigation. 
Epiphytic microalgae and water quality interaction at north Delta- Egypt




The dominant class was Bacillariophyta; it represented $95.7 \%$ of the total epiphytic species. Dinoflagellate was represented by 5 species, while both Cyanophyta and Chlorophyta were represented by only one species. The dominant species were Achnanthes linearis- var. pusilla,Achnanthes suchlandtii, Navicula incerta, Nitzschia closterium, Pinnularia brevicostata- var. leptostauron, Synedra actinastroides, Synedra utermoehlii. The recorded algal species might reflect the physico-chemical characteristics of water and in the meantime would be a consequent of water quality. In fact, water quality was found to be largely dependent on epiphytic algae, which function as biofilters with macrophyte communities (Oksiyuk et al., 1980; Kuzko, 1988).

The epiphytes standing crop on Phragmites australis were greatly detected at both surface and bottom levels with least detection at the middle level (Fig. 3).

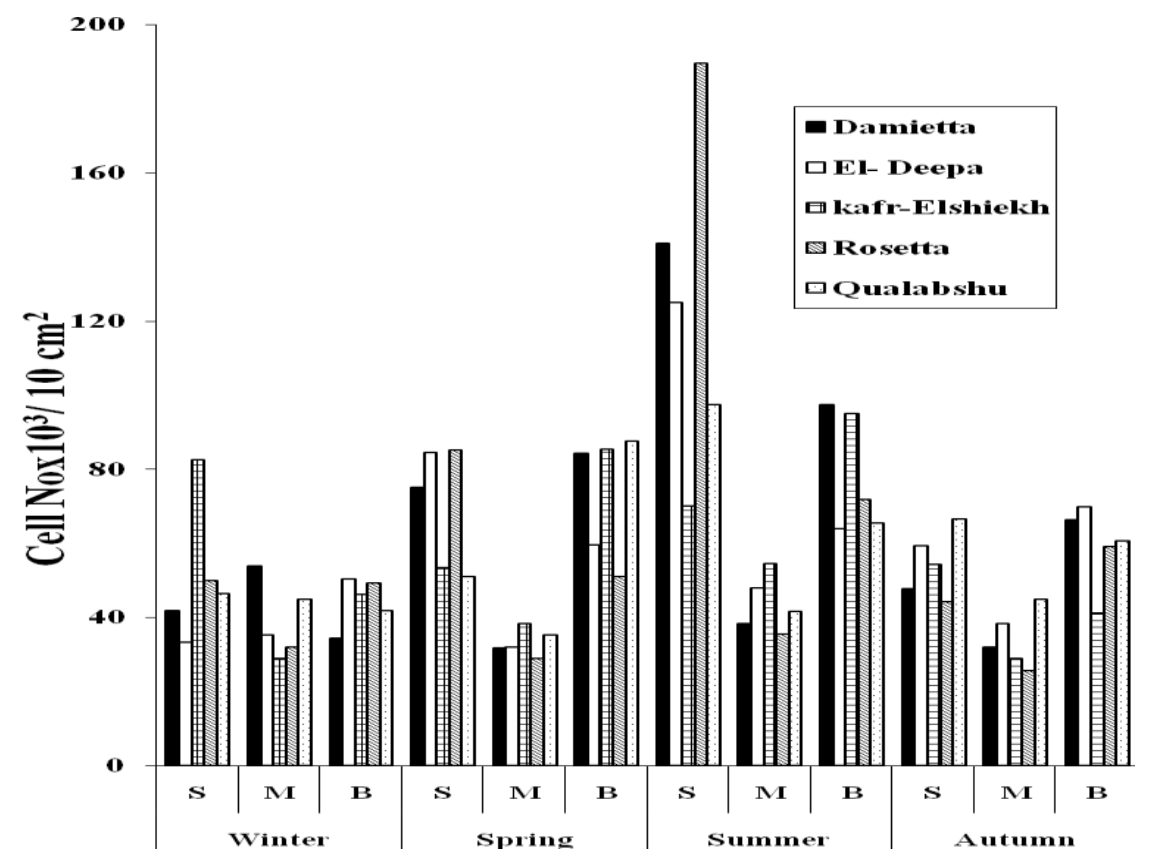

Figure 3. The seasonal variations of the mean epiphytic microalgal species standing crop on the surface of Phragmites australis plant at five stations

The highest value was recorded at Rosetta station in summer on surface level while the lowest value was recorded at El- Deepa station in winter. Similarly, Kafr- Elshiekh recorded the highest value in summer and the lowest one in 
Rosetta in autumn in the middle level. On the other hand, Damietta in winter and Qualabshu in spring showed the lowest and the highest standing crop in the bottom level respectively. These fluctuations might be related to pollution and the nutrient content in the water of the stations under investigation (Frankovich et al., 2006).

Meanwhile, there were significant variations in biomass of epiphytic species in these levels (Fig. 4). The highest detection of epiphytes was recorded at Rosetta in summer in both surface and bottom levels as well as El- Deepa in autumn in the middle level. On the contrary, the least detection was found at Rosetta in autumn in the middle as well as at Qualabshu in both spring and summer in middle and bottom levels, respectively. The different distribution of these epiphytic algae may be related to light intensity and trophic status of water. The light regime is the most important abiotic factor that influences growth and distribution of epiphytic algae (Muller, 1995). The species standing crop value of epiphytic microalgae was correlated positively with the nutrient content of the water (Elisabeth et al., 2003 and Cook, 2007).



Figure 4. The seasonal variations of the mean epiphytic microalgal biomass on the surface of Phragmites australis plant at five stations 
Cluster analysis of epiphytic algal species reveal that the samples of epiphytic algae on Phragmites australis were clustered into two main clusters, one for bottom level and the other for both middle and surface levels (Fig. 5). The latter cluster shows two subdivisions, one for each level. Therefore, each of the tested level seemed to be separated in a restricted cluster regardless the station investigated, however, middle level appeared to be related to surface rather than bottom level. On the other hand, there were similarities between Kafr-Elshiekh and Rosetta stations at bottom surface and also between El-Deepa and Damietta stations. At the middle level, more similarities were detected for epiphytes at ElDeepa and Kafr-Elshiekh stations. On the contrary, epiphytic algae at surface level of Rosetta were similar to those of Qualabshu. Bukholder et al. (1990) and Abdel - Baky (2006) reported that the grouping of the studied sites dependent mainly on the similarities between these sites.



Figure 5: Similarity dendrogram between stations at different seasons according to the abundance of the epiphytic species on Phragmites australis at three levels (surface, S; middle, M; Bottom, B) using Bray-Curtis measure (cluster analysis).

Diversity index as well as saprobity index are considered to be good biological indications to assess water quality and trophic status (Abdel- Baky, 2006). The obtained results revealed that the diversity index values through the period of investigation varied according to local site, season and level used. The value of this index ranged from 0.96 to 3.32 at the surface level in winter and summer at El-Deepa and Rosetta stations revealing that water quality was considered as heavy to slight polluted water, respectively. The decrease of 
diversity index may be related to the presence of organic pollution as a result of the discharge of wastes into an aquatic ecosystem (Polishchuk, 1999; Ferreira et al., 2005).



Figure 6. The seasonal variations of Diversity Index and Saprobity Index of epiphytic algae on Phragmites australis at five stations at three levels (surface, S; middle, M; Bottom, B). 
On the other hand, saprobic index values ranged from 0.60 to 2.6. The saprobity is an indication for the ability of an organism to develop in water body with certain degree of pollution. An increase of saprobic index may be due to an increase of the agricultural discharges and domestic sewage into the aquatic system leading to an increase of the trophic water state (Tilman, 1996). These findings illustrated a saprobity level fluctuated from Univocal oligosaprobity and universal $\alpha$ - mesosaprobity.

The present work concluded that there was a significant correlation between some of water parameters. These correlated characteristics could interfere with epiphytic microalgal distribution, biomass and abundance which, in turn, would reflect the physico-chemical analysis of water; Nevertheless, the diversity index revealed that water quality ranges from heavy to slight polluted water and the saprobity index indicated a univocal oligosaprobity and universal $\alpha$ - mesosaprobity.

\section{References}

Abdel-Baky, J. M. (2001). Effect of some wastes on the algal biodiversity in the Delta region of the River Nile. M. Sc. Thesis, Bot. Dept, Mansoura Univ., Egypt, pp377.

Abdel-Baky, J. M. (2006). Ecological studies on the dynamics of phytoplankton at Damietta Estuary of the River Nile. Ph. D. Thesis, Bot. Dept, Mansoura Univ., Egypt, pp399.

Abdel-Hamid, M. I.; Shaaban-Dessouki, S. A. and Skulberg, O. M. (1992). Water quality of the River Nile in Egypt I. Physical and chemical characteristics. Arch. Hydrobiol. Suppl., 90: 283 - 310.

Adam, M. S.; El-Sharouny, H. M. and Galal, H. M. (1993). Effect of some pollutants on Nile phytoplankton II-laboratory experiments. Bull. Fac. Sci., Assiut Univ., Egypt, 22 (2-D): 97 - 110.

Allen, S.; Grimshay H M; Parkinson, J. A. and Quarmby, C. (1974). Chemical analysis of ecological materials (Blackwell: Oxford): 565pp.

American Public Health Association (APHA) (1989). Standard methods for the examination of water and waste water, sewage and industrial wastes. $16^{\text {th }}$ Ed. New York, p. 1193.

Anna, R. A.; Thomas, A. F. and James, W. F. (2006). Variable responses within epiphytic and benthic microalgal communities to nutrient enrichment. Hydrobiol., 569: 423 - 434.

Aziz, Q.; Inam, A. S. and Siddiqi, R. H. (1996). Long term effects of irrigation with chemical industry wastewater. J. Environm. Sci. Health., A 31 (10): 2595 - 2620. 
Burkholder, J. M.; Wetzel, R. G. and Komparens, K. L. (1990). Direct comparison of phosphate uptake by adnate and loosely attached microalgae within an intact biofilm matrix. Appl. Environ. Microbiol., 56: 2882 2890.

Caccia, V. G. and Boyer, G. N. (2005). Spatial pattering of water quality in Biscayne Bay, Florida as a function of land use and water management. Marine Pollution Bull., 50 (11): 1416 - 1429.

Chapman, H. D. and Pratt, P. E. (1961). Methods of analysis for soils, plants and water. Division of Agric. Sc., Univ. of California,USA, pp. 184-203.

Clifford, H. T. and Stephenson, W. (1975). An introduction to numerical classification. Academic Press, London: 229p.

Cook, G. (2007). Benthic diatoms in the Salinas of the Dry Creek saltfields, South Australia. Hydrobiologia, 576 (1): 61 - 68.

Cronberg, G. (1982). Phytoplankton changes in lake Trumen induced by restoration. in: Long- term Whde-Lake studies and food- web experiments. Folia Limnologica Scandinavica, 18: 1-119.

Cyrus, Z. and Sladecek, V. (1973). A guide of organisms from waste water plants. Water Research Int. Prague, Czechoslovakia, 133:1-156.

Eli, A. L.; Stein, W. J. and Tuomo, S. (2004). Periphyton in running waterlong- term studies of natural variation. Hydrobiol., 521 : 63- 86.

Elisabeth, M. G.; Claudia, F. and Andrea, G. (2003). Epiphyte biomass and elemental composition on submersed macrophytes in shallow eutrophic lakes. Hydrobiol., 509 : 559 - $\mathbf{5 6 5}$.

El- Naggar, M. A. (2002). Comparative Studies of some Marine Algae in the Red Sea coast of Egypt. M. Sc. Thesis, Bot. Dept, Fac, Sci of Damietta, Mansoura Univ., Egypt, pp 225.

Ferreira, J. G.; Wolff, W. J.; Simas, T. C. and Brickei, S. B. (2005). Does biodiversity of estuarine phytoplankton depend on hydrology? Ecological Modeling., 187 (4): 513 - 523.

Frankovich, T. A.; Gaiser, E. E.; Zieman, J. C. and Wachnicka, A. H. (2006). Spatial and temporal distributions of epiphytic diatoms growing on Thalassia testudinum Banks ex Konig: relationships to water quality. Hydrobiologia, 569 (1): 259 - 271.

Ganf, G. G. (1974). Diurnal mixing and vertical distribution of phytoplankton in a shallow equatorial lake ( Lake George, Uganda). J. Ecol., 62: 611 - 629.

Goldsborough, L. G. and Hickman, M. (1991). A comparison of periphytic algal biomass and community structure on Scirpus validus and on a morphologically similar artificial substratum. J. Phycol., 27: 916-928.

Golterman, H. L. (1999). Quantification of P-flux through shallow, agricultural and natural wastes as found in wetlands of the Camargue (S-France): Hydrol., 392: 29 - 39. 
Golterman, H. L.; Glymo, R. S. and Ohnstad, M. A. M. (1978). Methods for physical and chemical analysis of fresh waters. $2^{\text {nd }} e d$. Blackwell scientific Publications, Oxford, London, 172.

Hans, W. P. (2006). Assessing and managing nutrient-enhanced eutrophication in estuarine and costal waters: intensive effect of human and climatic perturbations. Ecological Engineering, 76: 251 - 266.

Hendy, N.I. (1964). An introductory account of the smaller algae of British Coastal Water. Part v: Bacillariophyceae (Diatoms). London : HMSO, 74165.

Hindak, F.; Kamarek, J.; Marvan, P. and Ruzicka, J. (1975). Kluc Na Urcovanic Vytrousnych Rastlin, I. Diol. Riasy.

Janne, S. and Jani, H. (2005). Relationships between local population persistence, local and regional occupancy of species: distribution patterns of diatoms in boreal streams. J. Biogeagr., 32: 1971 - 1978.

Jüttner, I.; Rothfritz, H. and Ormerdo, S. J. (1996). Diatoms as indicators of river quality in Nepalese Middle Hills with consideration of the effects of habitat-specific sampling. Freshwat. Biol., 36: 475 - 486.

Kuzko, O. A. (1988). Epiphytic algal group in canals and their significance to water quality. Hydrobiol. J., 24 (6): $26-29$.

Lisa, A. D. and Fred, C. D. (2003). Effects of epiphyte load on optical properties and photosynthetic potential of the seagrasses Thalassia testudinum Banks ex Konig and Zostera marina L. Limnol.Oceanogr., 48: 456 - 463.

Lund, J. W. (1965). The ecology of the freshwater phytoplankton. Biol. Rev., 40: 231-293.

Madkour, F .F. (2000). Ecological studies on the phytoplankton of the Suez Canal. Ph. D thesis, Bot. Dept, Suez Canal Univ., Egypt, pp211.

Müller, U. (1994). Seasonal development of periphytic algae on Phragmites australis (Cav.) Trin. Ex Sten. In a eutrophic lake. Arch. Hydrobiol., 129: $273-292$.

Müller, U. (1995). Vertical zonation and production rates of epiphytic algae on Phragmites australis. Freshwater Biol., 34: 69 - 80.

Oksiyuk, O. P.; Stolberg, F. V. and Oleynik, G. N. (1980). The bioplateau and its use in canals. Gidrotekhnikai melioratsiya, No. 8: pp. 66-70.

Olmstes, I. and Gomez, M. (1995). Distribution and conservation of epiphytes on the Yucatan Peninsula. Selbyana, 17: 58 - 70.

Paul, V. Z. and Hopson, M. S. (1997). Quantification of epiphyte removal efficiency from submersed aquatic plants. Aqua. Bot., 58: 173 - 179.

Philipose, M. T. (1967). Chlorococcales. Indian Council of Agric. Res. New Delhi, 365p.

Polat, S. and Isik, O. (2002). Phytoplankton distribution, diversity and nutrients at the north- eastern Mediterranean coast of Turkey (Karatas- Adana). Turk. J. Bot., 26: 77- 86. 
Polishchuk, L. V. (1999). Contribution analysis of disturbances caused changes in phytoplankton diversity. Ecol., 80 (2): 721 - 725.

Prescott, A. C. W. (1978). How to known the fresh water algae "(third edition), 293.

Reynolds, C. S. (1976). Succession and distribution of phytoplankton in response to thermal stratification in a lowland mere, with special reference to nutrients availability. J. Ecol., 64 (2): 529-551.

ROPME (1983). Manual of oceanographic observations and pollutant analysis Methods. Rome, Al-Safat, Kuwait, pp. 283.

Shaaban-Dessouki, S. A.; Soliman, A. I. and Deyab, M. A. (1993). Environmental characteristics and nutrients distribution in Damietta Estuary of the River Nile. J. Environm. Sci., Mansoura Univ., Egypt, 6: 159 $-177$.

Shannon, C. F. and Weaver, W. (1963). The mathematical theory of communication. Univ. of Illinois Press, Urbana,USA, 117.

Sladecek, V. (1973). A guide of organisms from waste water plants: PrahaPodbaha, pp.156.

Strikland, J. D. H and Parsons, T. R. (1965). A practical handbook of seawater analysis. Bull. Fish. Res. Bd. Can., 167.

Sukran, D.; Diderm, K. And Nurhayat, D. (2002). A study on the epiphytic algae of the Nilufer stream (Bursa). Turk. J. Bot., $26: 219$ - 233.

Tilman, D. (1996). Biodiversity: population versus ecosystem stability. Ecology, 77: $350-363$.

Turkoglu, M. and Koray, T. (2002). Phytoplankton species' Succession and nutrients in the Southern Black sea (bay of Sinop). Turk. J. Bot., 26: 235252.

Vis, C.; Hudon, C. and Carignan, R. (2006). Influence of the vertical structure of macrophyte stands on epiphyte community metabolism. Fisheries and Aquatic Sciences, 63 (5): 1014- 1026.

Wood, R. B. (1975). Hydrobiological methods. Univ. Park Press, p. 32-33.

Zabelena, M. M; Kucelef, E. A; Prowkuna, A. U; Lafrehko-Sheshykofa, B. C. (1954). Bacillariophyta identification. Mexico, pp540.

Zaid, A. M. (1993). Ecological and photochemical studies on some marine algae common to Egyptian waters, M. Sc Thesis. Bot. Dept, Mansoura Univ., Egypt, pp.189.

Zimba, P. V. (1995). Epiphytic biomass in the littoral zone. Lake Okeechobee.Fl. Arch. Hydrobiol. Beih., 45 : 233 - 240. 


\section{الطحالب الدقيقة الملتصقة بالتباتات وعلاقتها بجودة المياه شمال الدلتاـ مصر

 \\ قسم النبات ـ كلية العلوم بلمياط - جامعة المنصورة - مصر}

يهدف هذا البحث الى دراسة التنوع و التوزيع والكتلة الحية للطحالب الدقيقة الملتصقة على سطح

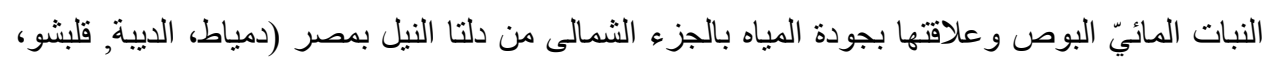
كفر الثيخ، رشيد) وذلك على مدار العام 2005. وسجّلت الدراسة وجود 141 نوع من الطحالب الدقيقة


فقط تتنمى للاينوفلاجيلات بينما الطحالب الخضر اءو الخضراء المزرقة فقد متّلت بنوع و واحد فقط لكل منهما. وقد استخدم هذا التتوع الطحلبى كدليل بيولوجى لتحديد مستوى جودة المياه حيث أظهرت النتائج أن المياه فى المنطقة بشمال دلتا مصر يتراوح مستوى التلوث بها مابين الخفيفة فى بعض الأماكن ومنوسطة التلوث فى معظم الأماكن و عالية التلوث فى بعض الأماكن الأخرى. 